\title{
Proverb and Mythopoeic Model of the World
}

\section{[Príslovie a mýto-poetický model sveta]}

\author{
Tatiana G. Bochina - Pavol Adamka
}

\section{DOI: 10.18355/XL.2015.08.02.18-27}

\begin{abstract}
Abstrakt
Článok sa zaoberá binárnym modelom, ktorý tvorí systémové jadro každého príslovia a sám osebe predstavuje archetypálny model poznania sveta tak, ako sa zrodil v hlbinách mýtu a tvorí základ naivného i jazykového obrazu sveta, pričom si zachováva svoj význam v normatívno-hodnotovom priestore súčasnej kultúry. Prvotný zmysel viacerých známych ruských prísloví sa interpretuje v korelácii s mýto-poetickým modelom sveta starých Slovanov, s motívmi a obrazmi d’alších žánrov l'udovej slovesnosti.

Klúčové slová

parémia, príslovie, model sveta, mýtus, kontrast, interpretácia
\end{abstract}

Mýto-poetický model sveta predstavuje kondenzované, zjednodušené zobrazenie celej sumy predstáv o svete, tak ako sa sformovali vo vnútri konkrétnej tradície, v jednote ich systémových a funkčných aspektov (porov. Mify, 1991-2: 161). Univerzálnym prostriedkom opisu sémantiky takéhoto modelu je systém binárnych príznakov, ktoré stoja vo vzájomnej opozícii. Analogický logicko-semiotický princíp je aj základom parémie: ,skutočnou témou každého príslovia alebo porekadla (úslovia) nie je konkrétna lexéma, ani myšlienka, a dokonca ani nejaká konkrétna oblast' l'udskej činnosti, ale akýsi invariantný pár protikladných podstát, ktoré determinujú zmysel v konkrétnom prísloví použitých obrazov ““ (Permyakov, 1988: 107). S mýto-poetickým modelom sveta príslovia spája nie len lingvokognitívny princíp kontrastu; mýtost' príslovia chápeme ako syntetickú komplexnost', obraznost', konkrétnost' a súčasne i neurčitost' „l'udových súdov“.

Mýto-kreatívne vedomie, ktoré je vlastné detskému mysleniu a prebieha primárne vpravej mozgovej hemisfére, je charakteristické takými osobitost'ami ako obraznost', konkrétnost', dominancia citových dojmov, nevyhranenost' osobnosti voči okolitému svetu, nedostatočnost' logicky determinovaných pojmov a abstrakcií (Deglin, 1983: 400). Najpodstatnejšími príznakmi mýtu, podla V. B. Kaseviča (Kasevich, 1996: 115-118) sú:

1) synkretickost’ - spojenie „teórie“ objasňujúcej svet, súhrnu etických, morálnych ustanovení, ktoré formujú normy správania sa a umenia ako emocionálno-obrazného odrazu reality;

2) komplexnost' a bezprostrednost' reakcie na svet, syntetizujúca apercepcia reality na základe emocionálnych dojmov;

3) personifikovanost' jeho elementov, ktorá sa prejavuje v tom, že mýtus neoperuje s abstraktnými pojmami, ale s predstavami o konkrétnych tvoroch, ktoré ich funkčne suplujú;

4) príklon kjednoduchým opozíciám, ktoré tvoria jeho podstatu a majú potenciál vzájomne sa neutralizovat';

1 «... подлинной темой какой-либо пословицы или поговорки является не то или иное слово, не та или иная мысль и даже не та или иная область человеческой деятельности, а некоторая инвариантная пара противопоставленных сущностей, к которой сводится смысл употребляемых в данной пословице образов»-preklad P.A. 
5) absolútnost' mytologického poznania (znalosti), jeho neohraničenost' v čase (panchronizmus) a v priestore.

Konvergencia mýtov k konceptuálnej jednoduchosti a schematickému zjednodušeniu objektov vyplýva z osobitého spôsobu myslenia, pri ktorom sa klúčové danosti zretel'ne vyčleňujú $\mathrm{z}$ reality, $\mathrm{z}$ jej všednosti a mnohotvárnosti, zložitosti a protirečivosti. „Túto formu osvojenia bytia môžeme opodstatnene charakterizovat' ako alternatívnu, resp. dualistickú, polarizujúcu, operujúcu absolútnymi antitézami - v opozícii k konkrétnemu, syntetizujúcemu, komparatívnemu, koordinujúcemu mysleniu" " (Halizev, 2002: 15). Najcharakteristickejšou je polarizácia všetkého so všetkým v tzv. druhotných, resp. „nových“ mýtoch, pričom pre archaické mýty bolo vlastné myslenie prekleňujúce, zmierňujúce protiklady v intuitívnom uchopení „,v̌̌eobecnej jednoty“ (porov. Halizev, 2002:16). Princíp binárneho modelovania sveta má svoje korene práve v archaickom mýte, v ktorom sa uprednostnila ekvipolentná, rovnocenná opozícia.

Väčšina príznakov mýtu je vlastná aj bežnému vedomiu. Tak ako mýtus, ktorý vzniká zo snahy nájst' pevné základy súcna (Avtonomova, 1988: 181), rovnako i existenciálna úroveň vedomia je nasmerovaná na potvrdenie neotrasitel'nosti základov bytia, života (Shul'ga, 1993: 26). Obvyklá kognitívna činnost' človeka, rovnako ako jeho mytologická adaptácia vo svete, je založená nie na pravidelnom a dôslednom využívaní logiky, ale na heuristických procesoch, ktoré operujú so stereotypnými a prototypovými štruktúrami. Mytologický model je v mnohom podobný naivnému modelu sveta; oba slúžia ako celostná a univerzálna „explanačná matrica pre štruktúrovanie skúsenosti“ (Kasevich, 1996: 79). Pre praktické, „bežné“ poznanie je charakteristická emocionálnost', bezprostredná reakcia; mýtus rovnako nebýva emocionálne neutrálnym pre svojich nositel'ov, ale „kolektívnym emocionálne-hodnotiacim obrazom sveta“ (Pivoev, 1991: 99).

Súčast’ou bežného vedomia sú rôznorodé životné princípy, ktoré boli osvojené v procese socializácie: zvyky, normy, tradície, sociálna skúsenost', kolektívne predstavy o svete, ,piliere zdravého zmyslu“, stereotypy a i. (porov. Shul'ga, 1993: 37). Jednou z foriem fixácie týchto princípov sú paremiologické jednotky. Preto nie je náhodou, že prísloviam je vlastná mytologickost' (túto ponímanie nie len v genetickom zmysle). Už F. I. Buslajev presvedčivo dokázal, že pôvod prísloví sa vzt'ahuje knajstaršiemu obdobiu „prvých zábleskov l’udského rozumu“ (Buslaev, 1861: 129). Okrem toho, mýtus i príslovie plnia rovnaké primárne funkcie - zabezpečit' konsolidáciu spoločenstva a optimálny životný tonus jeho členov (o mýte - Pivoev, 1991: 99; o prísloví - Nikolaeva, 2000: 151). Analogickými sú taktiež také charakterné znaky mýtu a príslovia, ako sugestívnost' a cyklickost'2.

Poetický princíp príslovia rozvíja, a súčasne i zachováva binárny model poznania, ktorá sa zrodil z mýtu a je základom naivného i jazykového obrazu sveta. Zjednodušená, schematická predstava o poznatel'nej skutočnosti, charakteristická pre kontrast, vytvára zovšeobecnený obraz, oprostený od redundantných podrobností, ktorý je z jednej strany logicky presný, a z druhej strany emocionálne výrazne nasýtený. Emocionálne-hodnotiaca vlastnost' binárnych opozícií a ich jednoduchost' súvisia s perlokutívnou silou príslovia, jej vplyvom nie len na logiku, ale skôr na pocity človeka, ktorý sa pomocou precedentného textu stáva súčastou kolektívneho vedomia.

${ }^{1}$ «Эту форму освоения бытия правомерно охарактеризовать как альтернативную, или дуалистическую, поляризующую, оперирующую жесткими антитезами - в противовес мышлению конкретному, синтезирующему, примеряющему, сопрягающему»- preklad P.A.

${ }^{2}$ T.j. periodicita opakovania tematiky a obrazov.

19 
V našej štúdii sa zameriame na interpretáciu obrazov radu známych ruských prísloví, konceptuálny obsah ktorých sa pokúsime analyzovat' vo vztahu k mýtopoetickému modelu sveta. Objektom výskumu sú konkrétne parémie, ktorých logická (i sémantická) výstavba zodpovedá modelu neidentickosti (дезидентификация): A nie je $B$, (pretože) $C$, t.j. odmietania podobnosti objektov, ktoré z pohl'adu dnešného recipienta patria $\mathrm{k}$ rozdielnym sféram života a preto sú prijímané ako originálne a dôvtipné obrazy (práca nie je vlk (zajac), št’astie nie je kôň, dážd' nie je kyjak a pod.) (podrobne pozri Bochina, 2002: 110-133). Základnou metódou nášho výskumu je spôsob hermeneutickolingvistickej interpretácie a odhalenia prvotného zmyslu parémií pomocou ich doslovného prečítania (pozri Airapetyan, 2000). Vo svojom výklade uplatňujeme taktiež sémantickoštylistickú a opisno-analytickú metódu, metódy kontextuálnej a konceptuálnej analýzy.

Už v roku 1876 v práci Zariekania ako druh ruskej l’udovej poézie N.V. Kruševskij konštatoval: „Jeden pohl'ad (...) na svet sa zamieňa druhým, no (...) úlomky predchádzajúceho svetonázoru neumierajú, ale nad’alej žijú, vrastajú do nového. Takýmto spôsobom, nové l'udové diela nevznikajú v pravom zmysle tohto slova, ale vytvárajú sa z už dávno existujúceho materiálu, čo má za následok, že nie je možné jednoznačne oddelit' diela jednej epochy od druhej: každé z nich predstavuje samo osebe akési navrstvenie. Takto „vrstvené“ diela l'udovej slovesnosti je všeobecne náročné analyzovat'. Pretože sa l'udové diela nevytvárajú, ale vyskladávajú, tak v nich, rovnako ako v hudobných dielach, nachádzame stále rovnaké motívy, t.j. stereotypné prostriedky (postupy) s minimálnymi variáciami. Analýza ludových diel musí byt', ako sa zdá, založená predovšetkým na špecifikovaní týchto motívov; toto je najstaršia a najpodstatnejšia čast' l'udových diel. Takéto vydelenie je samozrejme možné len vtedy, ak sú materiálom práce l'udové diela ako celok (a $\mathrm{k}$ tomu diela niekol'kých rodovo príbuzných národov), a nie len jeden akýsi ich druh"“(Krushevskii, 1998: 39).

Napríklad, ak chceme postihnút' prvotný zmysel všeobecne známeho príslovia Работа не волк, в лес не убежит, je potrebné analyzovat' sériu parémií s rovnakou logémou (,nie je nevyhnutné ponáhl'at' sa so splnením úlohy, práce“) a štruktúrou $A$ nie je B, (pretože) C: Дело не волк, в лес не убежит; Дело (работа) не медведь, в лес не уйдет; Работа не черт, в воду не уйдет; Дело не сокол, не улетит а i.; je potrebné nájst' „úlomky najstaršieho vnímania sveta“, usúvzt'ažnit' obrazy prísloví s hrdinami mýtov, motívmi ústnej l'udovej slovesnosti, s ruským jazykovým obrazom sveta.

Mýto-poetický model sveta je v prvom rade orientovaný na opis priestorovo-časových parametrov bytia. Pre temporálne koordináty sú najdôležitejšími

1 «Одно мировоззрение народа сменяется другим, но ... осколки прежнего мировоззрения не умирают, а продолжают жить, амальгамируясь с новым. Таким образом, новые народные произведения не возникают в строгом смысле слова, а складываются из давно существовавшего материала. Вследствие этого положительно невозможно разграничить произведения одной эпохи от другой: всякое из них представляет наслоение. Амальгамированные произведения народа вообще весьма трудно поддаются анализу. Так как народные произведения не создаются, а складываются, то в них, как и в музыкальных произведениях, встречаются постоянно одни и те же мотивы, т.е. стереотипные приемы, варьирующиеся весьма незначительно. Анализ народных произведений должен, кажется, состоять, прежде всего, в выделении таких мотивов; это древнейшая и существеннейшая часть народных произведений. Выделение такое, разумеется, возможно только тогда, когда материал работы составляют народные произведения вообще (и то нескольких родственных народов), а не один какой-нибудь род их»preklad P.A. 
opozície „deň - noc“, „leto - zima“, v ktorých sa prvé členy hodnotia pozitívne a druhé negatívne (Mify, 1991: 2, 161-163). V tomto vzt’ahu vystupuje vlk ako symbolická postava, prototypový predstavitel' noci a zimy. Významný výskumník slovanských ústnych podaní, povier a obyčajov A. N. Afanasjev tvrdí, že: „vlk, vd’aka svojej krvilačnej, zbojníckej povahe, získal v l’udových povestiach význam nepriatel'ského démona. V jeho obraze l’udová fantázia personifikovala nečistú silu nočného mraku, oblakov zatemňujúcich nebo a zimných hmiel “، (Afanasev, 1995-1, 377). Svoje závery podporil množstvom dôkazov zo slovanských a indoeurópskych jazykov a folklóru: „Ludová hádanka „,пишла темнота пид наши ворота, пытается лепеты: чи дома понура?" оznačuje vlka, psa a prasa. Slovo „temnota“ slúži ako metaforické označenie vlka, tak ako opačne, v iných hádankách slovo „vlk“ označuje nočný mrak: „пришел волк - весь народ умолк, ясен сокол пришел - весь народ пошел", t.j. s príchodom vlka - noci - l'udia išli spat' a s príletom jasného sokola - dňa, slnka - sa prebudili a ponáhl'ajú sa do práce; , u̧anцап (козел) по полю басуе, з'цапенятами гариуе; поты буде гариювати, поки вовк не станет спати“, t.j. mesiac a hviezdy, personifikované v podobách capa a kozliatok, budú svietit’ dovtedy kým potrvá noc, alebo metaforicky - pokým vlk nezal'ahne spat'. Dôkazy našich hádaniek sa potvrdzujú i indickou predstavou, podl'a ktorej Ranné Zore bojuje s vlkom a vytrháva z jeho papule slnko, t.j. zore vyvádza denné svietiace nebeské teleso z útrob nočného mraku. Epitetá vlčí a večerný sa inokedy využívajú ako rovnocenné; napr. Večernicu (Hesperus - planétu Venušu) nazývajú i ako Vlčia hviezda" (Afanasev, 1995-1, 378).

S predstavou vlka ako nepriatel'ského démona noci a zimy je spojených množstvo zákazov ohl'adne realizácie určitých druhov prác počas „temného času“ (t.j. v noci), počas „vlčích dní“ (t.j. v zimnom období, ktoré je v poverách spojené s besnením vlkov), počas viacerých kalendárnych dní, napr. dní, ktoré sú venované svätým - ochrancom vlkov (Slavianskie, 1995: 414, 427). Preto sa v prísloví Paбoma не волк, в лес не убежит zdá plne zákonitou opozícia práce a vlka, ktorý symbolizuje čast' dňa (roku) nevhodnú pre prácu.

Korelácia daného príslovia so synonymnými frazémami, v ktorých sa využívajú obrazy medved'a, čerta, sokola potvrdzuje, že protikladnost' práce a vlka nie

${ }^{1}$ «Волк, по своему хищному, разбойничьему нраву, получил в народных преданиях значение враждебного демона. В его образе фантазия олицетворила нечистую силу ночного мрака, потемняющих небо туч и зимних туманов» - preklad P.A.

2 «Народная загадка: "пришла темнота пид наши ворота, пытается лепеты: чи дома понура?" означает волка, собака и свинью. Слова темнота служит здесь метафорическим названием волка, как, наоборот, в следующих загадках слово волк принимается за метафору ночного мрака: "пришел волк - весь народ умолк, ясен сокол пришел - весь народ пошел", т.е. с приходом волка-ночи люди предаются покою, а с прилетом ясного сокола-дня пробуждаются от сна и спешат на работы; "цап-цап (козел) по полю басуе, з'цапенятами гарцуе; поты буде гарцювати, поки вовк не станет спати", т.е. месяц и звезды, представляемые козлом и козлятами, до тех пор будут светить, пока не исчезнет ночь, или, выражаясь метафорически, - пока станет бодрствовать волк. Свидетельство наших загадок подтверждается индийским представлением, по которому Утренняя Зоря сражается с волком и вырывает из его пасти светозарное солнце, т.е. зоря выводит дневное светило из недр ночного мрака. Эпитеты волчий и вечерний употреблялись иногда как равносильные; так, Вечерницу (Hesperus - планету Венеру) называют Волчьею звездою». - preklad P.A. 
je spojená len s konceptom času, ale i s konceptom priestoru. Predovšetkým máme na mysli opozíciu „svojho“ a „cudzieho“, v ktorej sa spájajú prírodno-prirodzené a kultúrno-sociálne korene. Ako vlk, tak i medved', čert a sokol sú typickými predstavitel'mi cudzieho sveta, ktorý stojí v protiklade k svetu človeka. Ako sme už naznačili, determinujúcim v symbolike vlka je príznak ,cudzi“", následkom čoho sa $\mathrm{s}$ ním spája všetko, čo pochádza „Zvonku“, napríklad ženích a noví príbuzní, mítvy predkovia, cudzinci atd’. Vlk ako mytologizovaná postava sa tradične stotožňuje s medved'om: vystupujú v rovnakých démonických predstavách, dostávajú sa do konfliktu s analogickými postavami, sú totožne prestrojení, platia voči nim rovnaké obranné zariekavania; registrujeme i analógie v spôsobe ich tabuizácie, dokonca mávajú i rovnaké pomenovanie: $\mathrm{v}$ rôznych oblastiach Ruska volajú slovom „бирюк“ ako vlka, tak i medved’a (pozri Dal', 1981-1: 88).

Príslovia Дело не волк, в лес не убежит; Дело (работа) не медведь, в лес не уйдет; Работа не черт, в воду не уйдет; Дело не сокол, не улетит zbližuje taktiež to, že sa v nich práca konfrontuje s predstavitel'mi cudzieho sveta, typické miesto prebývania ktorých sa konkretizuje priamo, alebo náznakmi v časti nasledujúceho komentára: pre vlka a medved'a - les, pre čerta - voda, pre sokola - otvorený priestor (nebo). Spomeňme i d’alšie príslovia: Волков бояться, в лес не ходить; Счастье, что волк: обманет, в лес уйдет; Соколу лес не в диво; Черт огня боится, а в воде селится; Правит, как черт болотом; Было бы болото, а черти будут, alebo l'udové pomenovania, napr. medved'a: лесник, леший, лесной черт, лесной архимандрит (podl'a Dal', 1981-2: 311). A. A. Potebňa v súvislosti s parémiou Как волка ни корми, он все в лес глядит, konštatoval, že „do lesa“ v danom prípade neoznačuje smerom „kde stoja stromy“, ale „von“ - „na tú stranu, ktorá je v protiklade všetkému domácemu, priatel'skému, sympatickému“ (Potebnya, 1989: 212). V súlade s analyzovanými prísloviami je zrejmé, že v myslení je práca bezpodmienečne spojená so „svojim“ (našim) svetom a nemôže zmenit' svoju lokalizáciu, opustit’ tento „náś“ svet - odtial' pochádza i myšlienka o stálom dostatku práce a zbytočnosti uponáhl'anosti pri nej.

Konštatujeme, že príslovie Работа не волк, в лес не убежит spočiatku vyjadrovala myšlienku stabilnej prítomnosti práce $\mathrm{v}$ živote človeka, ktorá bola až v neskoršom období zatienená odvodeným antonymickým významom, vktorom sa vyjadruje predstava o tom, že nie je dôležité sa s prácou ponáhl'at'. Pochopit' tento prvotný zmysel nám pomohlo jej usúvzt'ažnenie s mýto-moetickým modelom sveta Starých Slovanov ${ }^{1}$.

S mýto-poetickým modelom sveta tak alebo onak korelujú i d’alšie parémie so štruktúrou $A$ nie je $B$, (pretože) $C$. Je známe, že vzt’ahy komparácie, podobnosti, totožnosti a rozličnosti predpokladajú blízkost' porovnávaných objektov vo vedomí, v myšlienkovom móde (porov. Zolotova, 1998: 369). Obrazná neidentickost' sa taktiež opiera na prepojenost' subjektu a termínu porovnania $A$ nie je $B$ vo vedomí, bez ohl'adu na to, akými nestotožnitel'nými by sa zdali dnešnému nositel'ovi jazyka.

Uznávaná osobnost' v oblasti folklóru, A. A. Potebňa tvrdil, že negácia, popieranie $\mathrm{v}$ l'udovej poézii sa vyvinulo $\mathrm{z}$ kladného porovnávania ${ }^{2}$. Vo svojej klasickej práci Myslenie a jazyk uvádza: „,.. existencia akoby umelého príslovia

\footnotetext{
${ }^{1}$ Uvedená interpretácia bola prvýkrát publikovaná v časopise Русский язык в школе (Bochina, 2003) a bola podporená aj N.M. Šanskim: „V každom prípade, opozícia svojho (dom a práca) a cudzieho (les, vlk, medved'), stojí v prvopočiatkoch tohto príslovia“"(Shanskiy, 2003: 51; preklad P.A.).

2 «есть первоначально положительное сравнение и только впоследствии стирает с себя печать происхождения» (Potebňa, 1989: 194)
} 
„власть не сласть, а воля не завидная доля“ je možná len vd’aka tomu, že v jazyku sa stali príbuznými predstavy slobody a št’astia, predstavy, že práve vôla je závideniahodný osud. Kašubské príslovie „тьма не ест людей, но валит их с ног" predpokladá vieru, že tma skutočne požiera l'udí, čo bude zrejmejším, ak si spomenieme, že „тьма“ (pol’. čma, nočný motýl') je mytologická bytost', totožná so srbskou vešticou - požieračkou srdcí1، (Potebnya, 1989: 194). Rovnakú myšlienku rozvíja i v práci O niektorých symboloch v slovanskej l’udovej poézii: „„, Ююбовь,“ tvrdí príslovie, - „не пожар, а загорится, не потушишь“; z podobných neúplných porovnaní môžeme vždy takmer s určitost'ou tvrdit', že existujú plné, t.j. v tomto prípade, že láska je požiar“ (Potebnya, 1989: 299).

Aby sme postihli pôvod obraznej neidentickosti $A$ nie je $B$, je nevyhnutné vymedzit' prvotný zmysel pripodobenia nesúmerných veličín A a B. Často je negácia ukazovatel'om historickej blízkosti negujúcich sa objektov, ich previazanosti v národnom povedomí. V prísloví Дождь не дубина, не убьет; беда - не смерть, в гроб не уберет negácia identickosti dažd'a a kyjaka vyplýva $\mathrm{z}$ pohanskej viery $\mathrm{v}$ boha búrky Perúna, jedným $\mathrm{z}$ atribútov ktorého bola i bohatierska palica - blesk, v pôvodnom archetype - dubový kyjak (Afanasev, 1995-1,131). Táto viera sa odráža i v mnohých hádankách, napr. o daždi: На мху, на болоте гриб-волнуху заколотит; Голенастый с голенастым на кулачки бьются.

V starých povestiach o stvorení sveta sa hovorilo o vytvorení prvých l'udí z dreva a kameňa. A.N. Afanasjev písal o Perúnovi: „, čase jesenných búrok, bijúc svojim kamenným kladivom, drobiac a rozhadzujúc skaly - oblaky, vzýval k životu oblačných velikánov, skamenených chladným dychom zimy; hovoriac mytologickým jazykom: oživoval kamene a tvoril z nich plemeno obrov “" (Afanasev, 1995-2, 241; vydelené autormi). $\mathrm{V}$ minulosti boli predstavy o živote a kameni tesne vzájomne prepojené: kameň života, skamenený (= dočasne mŕtvy) život, oživit' kameňom a pod. Táto blízkost' $\mathrm{v}$ národnom povedomí robila život a kameň porovnatel'nými veličinami, $\mathrm{z}$ ich podobnosti sa $\mathrm{v}$ určitom období poznania vyformovala ich asymetria: Жизнь не камень: на одном месте не лежит, а вперед бежит.

Odmietanie identickosti brucha (rus. живота) a nitky Животы не нитка: надорвешь, не подвяжешь poukazuje na mytologické spodobenie trvania l'udského života a nat'ahajúcej sa nitky, ktorú odmeriavajú a pretínajú panny osudu: litovská priadka Werpeja, slovanské Rožanice (Rodjenice), grécke Moiry, rímske Parcae, románske Fée a germánske Norny (porov. Afanasev, 1995-3, 164-179). Podl'a predstáv Rusov, brucho je schránka života, na čo poukazuje i etymológia slova „живот“, spojeného s koreňom ži-, s jeho sémantickým významom „život človeka

1 «Как будто несколько книжная пословица: "власть не сласть, а воля не завидная доля" - возможна только потому, что в языке роднятся представления свободы и счастья, что воля есть именно завидная доля. Кашубская пословица: "тьма не ест людей, но валит их с ног" предполаг.ает мысль, что тьма действительно ест людей, что будет понятно, если вспомним, что тьма (польск. с̌та, ночной мотылек) есть мифическое существо, тождественное с серб. вештицею, съедающей сердце» - preklad P.A.

2 «"Любовь, - говорит пословица, - не пожар, а загорится, не потушишь"; но из подобных неполных сравнений можно всегда почти заключить о существовании полных, т.е. в настоящем случае, что любовь есть пожар»-preklad P.A.

3 «во время весенних гроз, ударяя своим каменным молотом, дробя и разбрасывая скалы-тучи, он призывал к жизни облачных великанов, окаменелых холодным дыханием зимы; говоря мифическим языком: он оживлял камни и творил из них исполинское племя» - preklad P.A. 
a zvierat'a (rus. животного); to jest bytosti živé, oživujúce telo, tvoriace pozemský život“", a frazeologické spojenia лишиться живота (umriet'), живот вечный (večný život). Chápanie života-brucha, ako nitky, roztrhnutie ktorej má za následok smrt’ nachádzame taktiež v parémii Дворянские животы и тонкие, да долгие: тянутся, да не рвутся; а посадские и толстые, да короткие (Dal', 1981-1: 540).

Mimoriadne názornou je skupina negujúcich prísloví o št’astí (pozri Bochina, 2013: 244-251): Счастье не корова: не выдоишь; Счастье не конь (не кляча): хомута не наденешь (не взнуздаешь); Счастье не лошадь: не везет по прямой дорожке; Не курочка (счастье), не прикормишь; Счастье не батрак: за вихор не притянешь; Счастье не палка, в руки не возьмешь; Счастье не кляп: в руки не возьмешь; В счастье - не в чурки: из руч не убьешь; В счастье - не в бабки: свинчаткой кону не выбьешь.

Bez ohl'adu na rôznorodost' objektov porovnávania, ktoré súčasný nositel' jazyka považuje za originálne, dôvtipné, duchaplné obrazy, a rozdielnost' motivácií, ktoré sú v základoch týchto „nečakaných“ komparácií, uvedené príslovia sú celistvým a logicky nadväzným zobrazením konceptu Št’astie. Zväzok významov, spojených $\mathrm{s}$ týmto konceptom, je relatívne komplexne definovaný V. Dalom v jeho slovníku: „счастье (со-частье, доля, пай): 1) рок, судьба, часть и участь, доля; 2) случайность, желанная неожиданность, талант, удача, успех, спорина в деле, не по расчету (указание на пресловутый русский фатализм!); 3) благоденствие, благополучие, земное блаженство, желанная насущная жизнь, без горя, смут, тревоги; покой и довольство “ (Dal', 1981-4: 471). Do tejto definície je nevyhnutné doplnit' pre mnohých neoddelitel'nú koreláciu št'astia s Bohom: „Samotné slovo boh, pôvodne označovalo (...) fatum. V sanskrte mu zodpovedá bhagas (od bhag - delit') čast', podiel, zlomok, a potom št'astie a najvyššia bytost', ktorá má vo svojich rukách všakovaké dary; tieto rozdel'uje medzi smrtel'níkov. (...) ... с-божие analogicky so slovom c-yacmue $\mathrm{v}$ rôznych slovanských jazykoch a dialektoch označuje alebo všeobecne majetok, vlastníctvo, bohatstvo ${ }^{1}$, alebo jeho konkretizáciu - chlieb ${ }^{2}$, hlavné bohatstvo rol'níka"“ (Afanasev, 1995-3:187).

Príslovia Счастье не корова: не вылоишь; Счастье не конь (не кляча): хомута не наденешь (не взнуздаешь); Счастье не лошадь: не везет по прямой дорожке svojou obraznost'ou siahajú až k predhistorickým časom, kedy hlavným bohatstvom nomádov boli ich stáda, dobytok (porov. Afanasev, 1995-1: 334); v agrárnom Rusku ${ }^{4}$ sa stotožnenie št'astia-bohatstva s kravou a koňom zachovalo až do 20. storočia, napr. Не то счастье, о чем во сне бредишь, а вот то счастье, на чем сидишь да едешь.

Príslovie Не курочка (счастье), не прикормишь sa geneticky spája s rituálmi sviatočného veštenia, kedy sa dievčatá o svojom osude, predovšetkým o manželstve, o budúcom partnerovi dozvedali podl'a toho, ktorý z predmetov (voda, chlieb, zlaté, strieborné a medené prstene a pod.) začne sliepka kl'uvat' ako prvé (pozri

\footnotetext{
${ }^{1}$ Napr. české ,zboži“ - tovar.

${ }^{2}$ Napr. slovenské „zbožie“ - obilie.

3 «Самое слово бог первоначально означало...fatum. В санскрите ему соответствует bhagas (от bhag - делить) - часть, доля, отломок, а потом счастие и высочайшее существо, имущее в своих руках всякие дары и разделяющее их между смертными» и далее: «с-божие аналогично с словом с-частие: в разных славянских наречиях оно означает или вообще - имущество, достояние, богатство, или в частности - хлеб, главное богатство земледельца»-preklad P.A.

${ }^{4}$ Rovnako ako tomu bolo i na Slovensku až do 50. rokov 20. storočia.
} 
Zalybin, 1990: 16-17); takýmto spôsobom sa sliepka stávala zvestovatel'om osudu, nadchádzajúceho št’astia alebo biedy.

Obraz, použitý v prísloví Cчастье не батрак: за вихор не притянешь, je svojim pôvodom spätý so starovekými personifikáciami Osudu a Št'astia v l’udových rozprávkach, povestiach, piesňach (bližšie pozri Afanasev, 1995-3, 194-206). V nich Št’astie-dobré vystupovalo ako verný sluha, paholok, nádenník, pomocník človeka, a jeho antipód Št’astie-zlé - ako lenivec, sedmospáč, lump a pijan.

Viera v to, že št'astie pochádza od Boha, sa prejavovala nie len v tradíciách „Božieho súdu“, hádania budúcnosti a „,veštenia“, ale taktiež vo zvyku losovat' (метать жребий ${ }^{l}$ ) v nejasných situáciách a získaný výsledok chápat’ ako rozhodnutie vševedúceho božstva. Odtial' pochádza i jedno z významov slova „жребий“ - „údel, osud, št’astie“" a ustálené frazeologizmy, napr.: Каждому свой жребий. От жеребья не уйдешь. Жеребий сыщет. Жеребий святое дело nepochybný, nesporný osud. Жеребей - Божий суд. Жеребий метать, после не хлопотать - nešražovat' sa, nenariekat'. Таланеи братеи, жеребеек батюшка. Жеребий дурак: родного отиа в солдаты отдаст (príklady z Dal', 1981-1: 534). V Rusku „метание жребия“ malo často formu pokonávania sa, akéhosi sút’aženia (конания): конаться - «меряться по палке или по веревке, метать жеребей» (Dal', 1981-2: 149). Je očividné, že s týto obyčajom je v podvedomí spojená blízkost' konceptov št'astia a palice, ich metonymické porovnanie, napr. Счастье, что палка: o двух концах, malo v neskoršom vývoji za následok podčiarkovanie ich protikladnosti v prísloviach ako napr.: Счастье не палка, в руки не возьмешь и Счастье не кляп ${ }^{2}$ в в руки не возьмешь.

Obyčaj rozlosovania bol neskôr prenesený i do oblasti hier: „конаться“ „означать кого для выхода счетом, в играх», "считаться конами, в бабки» (Dal', 1981-2: 149) - rozpočítavat' sa; „кон“ - «поприще, место игры, постановки“ miesto pre hru; „конить“ - «в играх, где бросают бабку, палку: перекидывать, бросать далее» (Dal', 1981-2: 154) - triafat' d'aleko, prehodit' ciel'. Rovnako i negácia identickosti št'astia a hry vo výrokoch $B$ счастье - не в чурки (играть): из руч не убьешь; В счастье - не в бабки (играть): свинчаткой кону не выбьешь піе je náhodná, ale je založená na ustálených asociáciách.

Všetky vyššie uvedené príslovia, ktoré podčiarkujú neidentickost' št’astia s tak rôznymi objektmi ako krava, kôň, sliepka, paholok, palica a hra, sami osebe predstavujú usporiadaný systém, ktorý reflektuje najstaršie chápanie osudu a štastia. Fixované v nich vnímanie št’astia najvýraznejšie zodpovedá dvom mytologickým modelom osudu - Osudu nadel'ujúcemu a Osudu hravému (pozri Arutyunova, 1999: 624-628). Naviac, objasňujúce časti daných prísloví (pretože C), bez ohl'adu na ich rôznorodost', systematicky poukazujú na fatalistický vzt’ah ruského národa k štastiu, ktoré sa nedá ani skrotit' (взять в руки), ani osedlat' (хомута не наденешь / не взнуздаешь) alebo prikŕmit', ani priblížit' (притянуть за вихор), ani podojit', t.j. využit' (zneužit') podl'a svojho uváženia, ani dobit' cielenou činnost'ou (из руч не убьешь, свинчаткой кону не выбьешь), ani dopredu predpovedat', kvôli nepredvídaným zvratom (не везет по прямой дорожке).

${ }^{1}$ V slovenčine danému výrazu najvhodnejšie zodpovedá frazeologizmus Hádzat' / hodit' si korunou, ktorý však plne nekoreluje so všetkými konotáciami ruského метать жребий.

${ }^{2}$ „Кляп“ - kolík, handrový šúl'ok, alebo palička, šikmo zrezaná, alebo zastrúhaná na koncoch, do ktorej sa udiera palicou v snahe dosiahnut', aby vyletela do vzduchu (RSS, 1989: 209; Dal', 1981-2: 123) 
Parémie sú spojené s mýto-poetickým modelom sveta nie len geneticky. Pochopit’ prvoplánový (prvotný) zmysel mnohých známych prísloví pomáha ich usúvzt'ažnenie s modelom sveta, svetonázorom Starých Slovanov, ako aj s motívmi a obrazmi druhých folklórnych žánrov. Binárny model, ktorý tvorí systémové jadro každého príslovia, sám osebe predstavuje archetypálny model poznania sveta tak, ako sa zrodil v hlbinách mýtu, tvorí základ naivného i jazykového obrazu sveta, pričom si zachováva svoj význam v normatívno-hodnotovom priestore súčasnej kultúry.

\section{References}

ADAMKA, P. 2009. Koncepty „nas“ - „cudzi“ a hladanie vlastnej narodnej identity. In: Europske kontexty interkulturnej komunikacie. Nitra: FF UKF, pp. 355-359. ISBN 978-80-8094-564-0

ADAMKA, P. 2011. Carovny svet pohanstva (ruske kulturologicke minimum pre studentov etnologie). In: Klucove kompetencie pre celozivotne vzdelavanie. Presov: PU, pp. 24-32. ISSN 1338-3388

AFANASEV, A.N. 1995. Poeticheskie vozzreniya slavyan na prirodu. Moscow: Sovremennyi pisatel'. ISBN 5-265-03309-2

AIRAPETYAN, V. 2000. Russkie tolkovaniya. Moscow: Yazyki russkoi kul'tury. ISBN 5-7859-0180-3

ARESTOVA, O.N. 2011. Intuitive understanding of proverbs. In: Voprosy Psikhologii, n. 2, pp. 129-138. ISSN 00428841

ARUTYUNOVA, N.D. 1999. Yazyk i mir cheloveka. Moscow: Shkola "Yazyki russkoi kul'tury". ISBN 5-7859-0027-0

AVTONOMOVA, V.N. 1988. Rassudok. Razum. Racional'nost'. Moscow: Nauka. ISBN 5-02-007939-1

BOCHINA, T.G. 2003. Poslovica i yazykovaya model' mira, ili pochemu Rabota ne volk: v les ne ubezhit. In: Russkii yazyk v shkole, n. 5, pp. 81-83. ISSN 0131-6141

BOCHINA, T.G. 2013, Russkie poslovicy o schast'e. In: Frazeologiya v mnogoyazychnom obshestve: sbornik statei mezhdunarodnoi frazeologicheskoi konferencii «EUROPHRAS». Kazan: Tatarskoe respublikanskoe izdatelstvo «Heter», pp. 244-251.

BOCHINA, T.G. 2002. Stilistika kontrasta: Ocherki po yazyku russkih poslovic. Kazan: Izdatelstvovo Kazanskogo universitetata. ISBN 5-7464-0760-7

BUSLAEV, F.I. 1861. Istoricheskie ocherki russkoi narodnoi slovesnosti i iskusstva. Russkaya narodnaya poeziya. Sankt-Peterburg: Tipografia tovarishchestva "Obshestvennaya pol'za".

DAL', V. 1981. Tolkovyi slovar' zhivogo velikorusskogo yazyka. Moscow: Russkiy yazyk.

DEGLIN, V.A. - BALONOV, L.YA. - DOLININA, I.B. 1983. Yazyk i funkcional'naya asimmetriya mozga. In: Uchenyje zapiski Tartuskogo universiteta, $\mathrm{n}$. 635. Tartu, pp. 31-42.

HALIZEV, V.E. 2002. Mifologiya XIX - XX vekov i literatura. In: Vestnik Moskovskogo universiteta. Ser.9. Filologiya, n. 3, pp. 7-21. ISSN 0201-7385

HORSKY, M. 2009. Konceptualizace času v českých a ruských proverbiálních rčeních. In: Slavia, vol. 78, n. 1-2, pp. 89-100. ISSN 00376736

KASEVICH,V.B. 1996. Buddizm. Kartina mira. Yazyk. Sankt-Peterburg: Centr "Peterburgskoe Vostokovedenie". ISBN 5-85803-050-5

KRUSHEVSKII, N.V. 1998. Izbrannye raboty po yazykoznaniyu. Moscow: Nasledye. ISBN 5-201-13322-3

MIFY narodov mira: Enciklopediya. 1991. / Red. S.A.Tokarev. Moscow: Sovetskaya Enciklopediya. ISBN 5-85270-016-9 
NIEIPORČIK, E.V. 2014. „Better to Die Than" About paradoxes of preference in paremiological pictures of the world. In: Studi Slavistici, vol. 11, pp. 123-141. ISSN 1824761

NIKOLAEVA, T.M. 2000. Ot zvuka k tekstu. Moscow: Shkola "Yazyki russkoi kul'tury". ISBN 5-458-22978-4

PERMYAKOV, G.L. 1988. Osnovy strukturnoi paremiologii. Moscow: Nauka.

PIVOEV, V.M. 1991. Mifologicheskoe soznanie kak sposob osvoeniya mira. Petrozavodsk: Izdatelstvo Kareliya. ISBN 5-7545-0548-5

POTEBNYA, A.A. 1989. Slovo i mif. Moscow: Pravda.

RSS. 1989. Rusko - slovensky slovnik. Bratislava: SPN. ISBN 80-08-00909-8

SCHUKLINA, T.J. 2014. Binary oppositions as a way of representing the Slavic culture (in the context of the Russian proverbs). In: Life Science Journal , vol. 11, n. 10, pp. 638-641. ISSN 10978135

SHANSKII, N.M. 2003. V dvuh slovah. In: Russkii yazyk v shkole, n. 5, pp. 51. ISSN 0131-6141

SHUL'GA, R.P. 1993. Iskusstvo v mire obydennogo soznaniya. Kiev: Naukova dumka. ISBN 5-12-003802-6

SLAVYANSKIE drevnosti: Etnolingvisticheskii slovar. 1995. / Red. N.I.Tolstogo. Moscow: Mezhdunarodnye otnosheniya. ISBN 5-7133-0703-4

ZABYLIN, M. 1990. Russkii narod, ego obychai, obryady, predaniya, sueveriya i poeziya. Reprintnoe vosproizvedenie izdaniya 1880 g. Moscow: "Kniga Printshop". ISBN: 5-7160-0001-1

ZHOLKOVSKIJ, A.K. 1978. At the intersection of linguistics, paremiology and poetics: On the literary structure of proverbs. In: Poetics, vol. 7, n. 3, pp. 309-332. ISSN 0304422X

ZOLOTOVA, G.A. - ONIPENKO, N.K. - SIDOROVA, M.YU. 1998. Kommunikativnaya grammatika russkogo yazyka. Moscow: Institut russkogo yazyka RAN. ISBN: 5-88744-050-3

Words: 4652

Characters: 33347 (18,53 standard pages)

Prof. Tatiana Gennadievna Bochina, DrSc.

Department of Russian as a Foreign Language

Institute of Philology and Intercultural Communication

Kazan (Volga) federal university

Kremlovskaya 18

420008 Kazan

Russia

tbochina@yandex.ru

Mgr. Pavol Adamka, PhD

Language Centre

Faculty of Arts

Constantine the Philosopher University in Nitra

Hodžova 1

94901 Nitra

Slovakia

padamka@ukf.sk 